\title{
FINANCIAL AND NON-FINANCIAL DISCLOSURE PRACTICES IN SELECTED AWQAF INSTITUTIONS
}

\author{
Muhammad lqmal Hisham Kamaruddin \\ Rosnia Masruki \\ Mustafa Mohd Hanefah \\ Faculty of Economics and Muamalat \\ Universiti Sains Islam Malaysia, Malaysia \\ E-mail: m.iqmalhisham@gmail.com
}

\begin{abstract}
It is undeniable fact that waqf becomes as one of tools used in order to alleviate inequality among people especially Muslim community. Basically, wagf fund is raised from the public and managed by mutawalli under waqf institution. As the intermediate party between waqif and beneficiaries, waqf institution is accountable for the management of waqf funds and need to disclose sufficient information pertaining to waqf fund itself. Good disclosure practices by waqf institution should cover both financial and non-financial information for all related waqf activities, programs and projects conducted. This includes such as corporate information, strategic information, financial performance information, financial statement information and non-financial performance information. To examine such disclosure practices, intensive content analysis was employed on waqf reporting information which is waqf annual report from three selected awqaf institutions namely, Perbadanan Wakaf Selangor (PWS), Pusat Wakaf MAIWP Sdn Bhd (PWM) and Majlis Ugama Islam Singapura (MUIS). The results revealed that financial statement information was the highest disclosure practice by selected awqaf institutions when it scores 100\% (385 out of 385 items), followed closely by strategic information $68.9 \%$ (62 out of 90 items), financial performance information $66.7 \%$ (80 out of 120 items), corporate information $61.7 \%$ (74 out of 120 items) and finally by non-financial performance information $37.5 \%$ (45 out of 120 items). Besides, several interesting and advanced disclosure practice by MUIS also highlighted and discussed as a benchmark for other awqaf institutions to disclose their waqf activities, programs and projects in the future.
\end{abstract}

Keywords: waqf disclosure; financial disclosure; non-financial disclosure; Islamic social accounting

\section{A. INTRODUCTION}

Waqf is currently becoming a trendy endowment method in Malaysia and Singapore nowadays. It has been promotes and practices in various scopes and kinds for ummah (public) interests. The rewards from waqf activities and programs are continuously as long as the waqf impacts still benefits the users. From economic perspectives, it is believed that waqf has the potential to promote socio-economic welfare and reduces inequality (Zuki, 2012). This is because waqf is been looks as another method other than obligation of Muslims toward zakat to reducing the gap between rich and poor level of wealth. In addition, history also shows that awqaf institutions are 
successfully providing social welfare services that many current states are struggle for it (Cizakca, 2002).

Since waqf assets should be existence for continuous contributions, the waqf assets must be managed and administrated by appropriate parties who are entrusted to become mutawalli (waqf manager) to ensure that benefit of waqf are reach to ummah at general (Rani \& Aziz, 2010). Mutawalli as a trustee for waqf assets are entitle to preserve and develop the properties that had been donated, growing the waqf assets for continuous benefits and also to keep the waqf assets from loss and damage (Shafii et al., 2014). Besides, mutawalli also needs to ensure that benefit of waqf are targeted and according to waqf donors' will.

The relationship between mutawalli and waqif (waqf donors) can be referred as traditional agency theory. In this theory, agent (mutawalli) is responsible to manage waqf assets given by principal (waqif) and accountable with all decision made along in managing waqf assets. This relationship is known as accountability and it can be discharged by giving all disclosure needed by principal (Laughlin, 1990; Gray et al., 1996). The disclosure demands by principal mostly on financial matters and proper accounting practices are vital for this purpose.

Meanwhile, Ihsan (2007) stated that accountability for waqf can be discharged if mutawalli adopting Islamic accounting system. Further, Ihsan and Adnan (2009) in waqf accountability model stated that mutawalli need to disclose reports towards waqif, waqf board of awqaf institution, beneficiaries and ummah. However, this model has not highlighted on what kind of disclosure needs to be disclosed and the priorities of awqaf institutions' stakeholders should be focused for.

On the other hand, Abdul Rahman (2003) stated that there are four objectives need to be achieved in accounting disclosure for Islamic organisation including awqaf institutions. The first two objectives are to avoid Islamic prohibition such as riba' (interest), maysir (gambling) and gharar (uncertainty), and the second one are the obligation to pay zakat. Meanwhile, other two objectives are to fulfil social responsibility and full disclosure practices. Regarding full disclosure practice, this is based on adequate disclosure where awqaf institutions do not need to disclose everything but to disclose all disclosure needed by both internal and external stakeholders (Kamaruddin \& Ramli, 2015).

At present, there are lot of waqf activities and programs conducted in Malaysia and Singapore. For example, there is a number of waqf education activities and programs which purposely to give continuous education toward beneficiaries either in primary, secondary or even tertiary educational levels. Besides, there are also several waqf medical activities and programs such as waqf dialysis, waqf mobile clinics and chain of waqf hospitals which purposely to provide health services. In addition, there are also a lot of development and investment on waqf funds especially on public benefits such as mosques, schools, shop lots, hotels, and even owning strategic businesses under waqf shares. Last but not least, there is also few waqf society and environmental activities and programs such as community engagements, refugees relief aids, halal awareness programs, waqf trees, and waqf gardens. All these types of waqf involve with different types of waqf assets and unlikely, there are no separate account according to types of waqf assets (Zain, 2005), and also no separation between types of waqf assets for disclosure and reporting purposes (Hisham, 2006).

Therefore, this study aims to examine current financial and non-financial disclosure practices in three selected awqaf institutions in Malaysia and Singapore. Besides, this study also compares and highlights in details several discolsure elements such as corporate information, strategic information, financial performance information, financial statements information and non-financial 
performance information. Besides, this study also identify and discussed several good waqf disclosure practices among selected awqaf institutions. Significant contribution in this study is to provide empirical data on waqf disclosure practices in three selected awqaf institutions in Malaysia and Singapore. This study also opens to potential development of the waqf disclosure practices for future research.

\section{B. METHODS}

This research aims on waqf disclosure practices for both financial and non-financial aspects by awqaf institutions in Malaysia and Singapore. This study focuses on three selected awqaf institutions located in Malaysia and Singapore which are Perbadanan Wakaf Selangor (PWS), Pusat Wakaf MAIWP Sdn Bhd (PWM) and Majlis Ugama Islam Singapura (MUIS). These three selected awqaf institution are chosen due to several reasons. First, it is notable that waqf administration in Malaysia is under jurisdiction of each State Islamic Religious Councils (SIRCs). Among SIRCs, only few of them are specifically and publicly disclose their waqf activities and programs annually including PWS and PWM. For Singapore case, MUIS is the only authorized institution by Singapore government to administrate waqf funds. Second, both Selangor and Wilayah Persekutuan are the most advanced and wealthy states in Malaysia. Therefore, it is believed that PWS and PWM are handling huge number of waqf funds as compared to awqaf institutions. Last but not least, PWS and PWM is among few awqaf institutions who are established separately from SIRCs in order handle waqf matters as compared to other SIRCs which still handling waqf matters under the single entity. The summary of these three selected awqaf institutions are as follow:

\section{Perbadanan Wakaf Selangor (PWS), Majlis Agama Islam Selangor (MAIS)}

Perbadanan Wakaf Selangor (PWS) was established from the consent of Selangor Ruler, His Royal Highness Sultan of Selangor on 11th January 2011 and was gazette on 3rd February 2011. Previously on 30th October 2009, His Royal Highness Sultan of Selangor ordered for Majlis Agama Islam Selangor (MAIS) to empower waqf administration by establishing a separate waqf entity as similar to zakat institution. Therefore, a new separate waqf entity known as PWS is established from this order, parallel with Section 8 of the Administration of the Religion of Islam (State of Selangor) Enactment 2008 that MAIS is eligible to establish a body that is suitable to administrate and manage activities that serve its waqf initiatives (PWS, 2017).

PWS is one of the bodies established to carry specifically on waqf objectives by MAIS which is to administrate waqf funds including collection, management and distribution processes. Specifically, PWS's roles and functions are as follow:

- Advise the MAIS with respect to policies, measures, measures to be taken and taken to promote the development of waqf properties and products;

- Implementing and affecting any policy, direction or order of the Council in respect of the development of waqf properties and products;

- Develop, adopt and implement policies, measures and measures on the development of waqf assets and products;

- Acting as a coordinating agency in the rapid implementation of waqf property and product development;

- Planning, developing, implementing and promoting the development and implementation of waqf assets and products; 
- Manage and carry out the operation and maintenance of waqf properties including facilities, infrastructure, premises and equipment in the area of waqf property; and

- Encourage, coordinate and conduct research and development in all aspects of waqf property and products.

PWS is led by a chief executive officer (CEO), who is responsible to report to the PWS's board of directors (BOD). The BOD consists of 11 members from various backgrounds such as accounting, business, religious, legal, architecture and land. The BOD is responsible in governing and implementing all waqf projects and activities runs by PWS. The BOD is also responsible to the waqf management collected mainly from public at large. For management level, PWS has four departments consisting of Finance Department, Administration Department, Marketing and Da'wah Department and also Research and Investment Department. In addition, PWS also have a separate Internal Audit Unit that responsible for internal audit processes. Moreover, although it's headquarter located at Shah Alam, Selangor, PWS also appointed nine waqf officers under Marketing and Da'wah Department, each waqf officer responsible for waqf collection in all nine districts in Selangor.

\section{Pusat Wakaf MAIWP Sdn Bhd, Majlis Agama Islam Wilayah Persekutuan (MAIWP)}

Majlis Agama Islam Wilayah Persekutuan (MAIWP) was established on 1 February 1974 simultaneously with the establishment of the Federal Territory of Kuala Lumpur. Its establishment is to take care of Islamic affairs in the Federal Territory of Kuala Lumpur which was previously placed under the Selangor state government. Meanwhile, Pusat Wakaf MAIWP Sdn Bhd (PWM) was established in 22nd August 2014 due to the increasing in public's awareness on the importance of waqf and waqf applications received by MAIWP (MAIWP, 2017).

PWM is one of the bodies established to carry specifically on waqf objectives by MAIWP which is to administrate waqf funds including collection, management and distribution processes. Specifically, PWM's roles and functions are as follow:

- Manage acceptance of waqf from the public.

- Administer and safeguard the properties of waqf to be properly protected.

- Provide clear understanding to the public about the concept and practice of real waqf.

- Improve the appreciation of waqf practices amongst the public to ensure that Islamic teachings continue to excel.

- Provide widespread exposure to the public on the importance of property development.

PWM is led by a chief executive officer (CEO), who is responsible to report to the PWM's board of directors (BOD). The BOD consists of members from various backgrounds such as accounting, business, religious, legal, architecture and land. The BOD is responsible in governing and implementing all waqf projects and activities runs by PWM. The BOD is also responsible to the waqf management collected mainly from public at large.

\section{Majlis Ugama Islam Singapura (MUIS)}

Majlis Ugama Islam Singapura (MUIS) which also known as the Islamic Religious Council of Singapore, was established as a statutory body in 1968 when the Administration of Muslim Law Act (AMLA) came into effect. Under AMLA, MUIS is to advise the President of Singapore on all matters relating to Islam in Singapore (MUIS, 2017). 
The role of MUIS is to see that the many and varied interests of Singapore's Muslim community are looked after. In this regard MUIS is responsible for the promotion of religious, social, educational, economic and cultural activities in accordance with the principles and traditions of Islam as enshrined in the Holy Quran and Sunnah. The Council of MUIS is the overall decision- making body and is responsible for the formulation of policies and operational plans. The Council comprises the President of MUIS, the Mufti of Singapore, persons recommended by the Minister- in-Charge of Muslim Affairs and other persons nominated by Muslim organizations. All members of the Council are appointed by the President of Singapore.

The waqf administration is under the Zakat and Waqf Strategic Unit in MUIS. All administrative and management matters with respect to the selling, development of waqf assets will be decided by MUIS senior management and MUIS Council. Where there are shariah issues the matter shall be heard in the Fatwa Committee. Any investments, purchases or financial obligations or implications which exceed the amount of $\$ 5,000,000$ will need the Minister's approval. Note that the department which oversees the waqf administration (Zakat and Waqf Strategic Unit of MUIS) will oversee the whole compliance with regards to the three types of administrator of the waqf that is the trustee which is the private and corporate trustees i.e. BMT and thirdly Warees Investments Pte. Ltd who acts as the agents of MUIS waqf which is not managed by the other two groups.

In order to examine current waqf disclosure by three selected awqaf institutions, a waqf disclosure index for both financial and non-financial aspects is used. This index is adapted from previous waqf reporting practices study done by Masruki et al. (2016). Each selected awqaf institutions' annual reports are analyzed for five consecutive years which is from year 2011 to year 2015. This is because some of the selected awqaf institutions yet to disclose their annual report for 2016. The levels of waqf disclosure are categorized into five disclosure elements which are: (i) corporate information; (ii) strategic information; (iii) financial performance information; (iv) financial statement information; and (v) non-financial performance information (Masruki et al., 2016). Table 1 list all items and disclosure elements for the waqf disclosure index that been adapted in this study.

\begin{tabular}{cc} 
& $\begin{array}{c}\text { Table } \\
1 . \\
\text { Waqf Disclosure } \\
\text { Index }\end{array}$ \\
\hline Waqf Disclosure Elements & \multicolumn{1}{c}{ Element Items (Indicators) } \\
\hline Corporate Information & Establishment and \\
& operation Purpose and \\
objectives Structure of & organization Board of \\
directors & Ethical operational \\
policies & Personn \\
el & Personnel \\
development \\
Governance
\end{tabular}


Government borrowing/grant/guarantee

Forward looking

Statistic disclosure

$\mathrm{S}$

Financial Performance Information

Financial review

Investme

nt

Actual to budget comparison

Financial performance ratios

Administration to total expenses

Program expenses/total expenses

Net rental income and expenses/rental income

Investment income/average investment 
Expenditure by activities/income by activities

\begin{tabular}{|c|c|}
\hline \multirow{7}{*}{$\begin{array}{l}\text { Financial Statement Information } \\
\text { (Statement of Financial } \\
\text { Position) }\end{array}$} & $\begin{array}{l}\text { Total non-current assets at cost } \\
\text { Long-term investments }\end{array}$ \\
\hline & Long-term \\
\hline & debtors Current \\
\hline & assets Current \\
\hline & liabilities Long- \\
\hline & term liabilities \\
\hline & Deferred \\
\hline \multirow{12}{*}{$\begin{array}{l}\text { Financial Statement Information } \\
\text { (Statement of Comprehensive } \\
\text { Income) }\end{array}$} & liabilities \\
\hline & Deferred credits from government grants \\
\hline & $\begin{array}{l}\text { Reserves } \\
\text { Revenue by source of funds }\end{array}$ \\
\hline & Revenue by services rendered \\
\hline & Other incoming revenue \\
\hline & Total revenue \\
\hline & Expenditure by services \\
\hline & Expenditure by functions \\
\hline & Administration and governance \\
\hline & costs Total expenditure \\
\hline & Other recognized gains/losses \\
\hline & Surplus/deficit \\
\hline \multirow{7}{*}{$\begin{array}{l}\text { Financial Statement Information } \\
\text { (Other Financial Statements) }\end{array}$} & Total fund brought \\
\hline & $\begin{array}{l}\text { forward (bf) Total fund } \\
\text { carried forward (c/f) }\end{array}$ \\
\hline & Statement of assets and liabilities \\
\hline & Statement of cash flows \\
\hline & Notes to the accounts \\
\hline & Audit certificate \\
\hline & Auditor index rating \\
\hline \multirow[t]{10}{*}{ Non-Financial Performance Information } & Performance target and objectives \\
\hline & Input \\
\hline & Output \\
\hline & Outcome \\
\hline & Efficiency \\
\hline & Effectivene \\
\hline & ss \\
\hline & Productivity \\
\hline & measures \\
\hline & Customer satisfaction measures \\
\hline
\end{tabular}

Source: Adopted from Masruki et al. (2016)

Based on Table 1, there are a total of 57 items for all five waqf disclosure elements. For recording process, binomial logic will be used as suggested by previous study conducted by Ramli and Kamaruddin (2017) in similar Islamic religious institutions in Malaysia. In this case, a score of 1 will be assigned for each item disclosed, while a score of 0 will be assigned if the item is not disclosed. It means that the total score for each awqaf institution is 285 (57 items - 5 years). The results from waqf disclosure practices among three selected awqaf institutions are presented and discussed in the following section. 


\section{RESULTS AND DISCUSSIONS}

In this section, evaluation on waqf disclosure practices among three selected awqaf institutions had been categorized into several types of disclosure elements. This includes corporate information, strategic information, financial performance information, financial statements information and nonfinancial performance information. Each of these waqf disclosure elements has its own identified items as an indicator. In this case, presentation of results is based on each waqf disclosure element, which is the main focus for this study. 
For waqf disclosure - corporate information items listed for this study includes: (1) establishment and operation; (2) purpose and objectives; (3) structure of organization; (4) board of directors; (5) ethical operational policies; (6) personnel; (7) personnel development; and (8) governance disclosure. From these eight corporate information indicators, all three selected awqaf institutions are disclosed for establishment and operation, purpose and objectives and board of director items. However, only PWM is disclosed on structure of organization and MUIS is disclosed on personnel item started in 2013. While, only personnel development item is not disclosed by any of three selected awqaf institutions.

Based on the result, MUIS is leading for waqf disclosure - corporate information when it scores $65 \%$ (26 items), followed closely by PWM 62.5\% (25 items) and the least is PWS with $57.5 \%$ (23 items). Moreover, governance disclosure provided by MUIS can be said as the most informative when it disclosed list of special panels and committees, list of volunteers and list of beneficiaries as compared to governance disclosure by PWS and PWM. In overall, it can be concluded that waqf disclosure - corporate information practices by these three selected awqaf institutions still in moderate level. Table 2 shows the result of analysis on waqf disclosure - corporate information for all three selected awqaf institutions.

\begin{tabular}{lcccc} 
& $\begin{array}{c}\text { Table } \\
2 . \\
\end{array}$ & & & \\
& $\begin{array}{c}\text { Waqf } \\
\text { Disclosure - Corporate } \\
\text { Information }\end{array}$ & & \\
\hline & Items & PWS & PWM & MUIS \\
\hline Establishment and & 5 & 5 & 5 \\
Purpose and objectives & 5 & 5 & 5 \\
Structure of & 0 & 5 & 0 \\
Board of directors & 5 & 5 & 5 \\
Ethical operational & 5 & 0 & 5 \\
Personnel & 0 & 0 & 3 \\
Personnel development & 0 & 0 & 0 \\
Governance disclosure & 3 & 5 & 3 \\
TOTAL & 23 & $\mathbf{2 5}$ & $\mathbf{2 6}$
\end{tabular}

Meanwhile, waqf disclosure - strategic information items listed for this study includes: (1) chairman report; (2) performance and achievement; (3) summary facts and figures; (4) government borrowing/ grant/guarantee; (5); forward looking disclosure; and (6) statistics. From these six strategic information indicators, all three selected awqaf institutions are disclosed for chairman report item. In addition, both PWM and MUIS disclosed for performance and achievement, government borrowing/grant/guarantee, forward looking disclosure and statistics items. However, only MUIS is disclosed on summary facts and figures item.

Based on the result, MUIS is leading for waqf disclosure - strategic information when it scores 100\% (30 items), followed by PWM 83.3\% (25 items) and the least is PWS with 23.3\% (7 items). Interestingly, performance and achievement provided by PWM are tallied with its key performance index (KPI). In overall, it can be concluded that waqf disclosure - strategic information practices by MUIS and PWM is in high level, while PWS waqf disclosure - strategic information is still in weak level. Table 3 shows the result of analysis on waqf disclosure - strategic information for all three selected awqaf institutions. 


\begin{tabular}{lcccc}
\multicolumn{1}{c}{$\begin{array}{c}\text { Table } \\
\text { 3. } \\
\text { Waqf Disclosure - Strategic } \\
\text { Information }\end{array}$} & PWS & PWM & MUIS \\
\hline \multicolumn{1}{c}{ Items } & 5 & 5 & 5 \\
\hline Chairman report & 0 & 5 & 5 \\
Performance and achievement & 0 & 0 & 5 \\
Summary facts and figures & 0 & 5 & 5 \\
Government borrowing/grant/guarantee & 0 & 5 & 5 \\
Forward looking disclosure & 2 & 5 & 5 \\
Statistics & 7 & 25 & 30 \\
TOTAL & 25 \\
\hline
\end{tabular}

Next, waqf disclosure - financial performance information items listed for this study includes: (1) financial review; (2) investment; (3) actual to budget comparison; (4) financial performance ratios; (5); administration to total expenses; (6) program expenses/total expenses; (7) net rental income and expenses/rental income; (8) investment income/average investment; and (9) expenditure by activities/income by activities. From these nine financial performance information indicators, none selected awqaf institutions are disclosed on actual to budget comparison. Meanwhile, other financial performance disclosure indicators are disclosed by both PWM and MUIS. Worst, PWS yet to disclose any financial performance information items listed in this study.

Based on the result, both MUIS and PWM score $88.89 \%$ (40 items) for waqf disclosure - financial performance information. On the other hand, PWS scores zero (0 item). In addition, all financial performance information are disclosed in the operation report section in MUIS's annual reports, while all financial performance information are disclosed in the chairman report section in PWM's annual reports. In overall, it can be concluded that waqf disclosure - financial performance information practices by MUIS and PWM is in high level, while PWS waqf disclosure - financial performance disclosure is still in weak level. Table 4 shows the result of analysis on waqf disclosure financial performance information for all three selected awqaf institutions.

\begin{tabular}{|c|c|c|c|}
\hline $\begin{array}{r}\text { Table } \\
4 . \\
\begin{array}{c}\text { Waqf Disclosure }- \text { Finan } \\
\text { Informati }\end{array}\end{array}$ & rmanc & & \\
\hline Items & PWS & PWM & MUIS \\
\hline Financial review & 0 & 5 & 5 \\
\hline Investment & 0 & 5 & 5 \\
\hline Actual to budget comparison & 0 & 0 & 0 \\
\hline Financial performance ratios & 0 & 5 & 5 \\
\hline Administration to total expenses & 0 & 5 & 5 \\
\hline Program expenses/total expenses & 0 & 5 & 5 \\
\hline Net rental income and expenses/rental income & 0 & 5 & 5 \\
\hline Investment income/average investment & 0 & 5 & 5 \\
\hline Expenditure by activities/income by activities & 0 & 5 & 5 \\
\hline TOTAL & 0 & 40 & 40 \\
\hline
\end{tabular}

Further, waqf disclosure - financial statement information (statement of financial position) items listed for this study includes: (1) total non-current assets at cost; (2) long-term investments; (3) longterm debtors; (4) current assets; (5); current liabilities; (6) long-term liabilities; (7) deferred liabilities; 
Financial and Non-Financial Disclosure Practices in Selected Awqaf Institutions

(8) deferred credits from government grants; and (9) reserves. From these nine financial statement information (statement of financial position) indicators, all three selected awqaf institutions are disclosed for all financial statement information (statement of financial position) items. 
Therefore, all three PWS, PWM and MUIS score 100\% (45 items) for waqf disclosure - financial statement information (statement of financial position). This happens as all three selected awqaf institutions are responsible to prepare such financial statement and being go through external audit processes annually. In overall, it can be concluded that waqf disclosure - financial statement information (statement of financial position) practices by PWS, PWM and MUIS is in high level. Table 5 shows the result of analysis on waqf disclosure - financial statement information (statement of financial position) for all three selected awqaf institutions.

Table

5.

Waqf Disclosure - Financial Statement Information (Statement of Financial Position)

\begin{tabular}{lccc}
\hline \multicolumn{1}{c}{ Items } & PWS & PWM & MUIS \\
\hline Total non-current assets at cost & 5 & 5 & 5 \\
Long-term investments & 5 & 5 & 5 \\
Long-term debtors & 5 & 5 & 5 \\
Current assets & 5 & 5 & 5 \\
Current liabilities & 5 & 5 & 5 \\
Long-term liabilities & 5 & 5 & 5 \\
Deferred liabilities & 5 & 5 & 5 \\
Deferred credits from government grants & 5 & 5 & 5 \\
Reserves & 5 & 5 & 5 \\
TOTAL & 45 & $\mathbf{4 5}$ & $\mathbf{4 5}$ \\
\hline
\end{tabular}

For waqf disclosure - financial statement information (statement of comprehensive income) items listed for this study includes: (1) revenue by source of funds; (2) revenue by services rendered; (3) other incoming revenue; (4) total revenue; (5); expenditure by services; (6) expenditure by functions; (7) administration and governance costs; (8) total expenditure; (9) other recognized gains/losses; (10) surplus/deficit; (11) total fund brought forward (bf); and (12) total fund carried forward (c/f). From these 12 financial statement information (statement of comprehensive income) indicators, all three selected awqaf institutions are disclosed for all financial statement information (statement of comprehensive income) items.

Therefore, all three PWS, PWM and MUIS score 100\% (60 items) for waqf disclosure - financial statement information (statement of comprehensive income). This happens as all three selected awqaf institutions are responsible to prepare such financial statement and being go through external audit processes annually. In overall, it can be concluded that waqf disclosure - financial statement disclosure (statement of comprehensive income) practices by PWS, PWM and MUIS is in high level. Table 6 shows the result of analysis on waqf disclosure - financial statement information (statement of comprehensive income) for all three selected awqaf institutions.

Table

6.

Waqf Disclosure - Financial Statement Information (Statement of Comprehensive Income)

\begin{tabular}{lccc}
\hline \multicolumn{1}{c}{ Items } & PWS & PWM & MUIS \\
\hline Revenue by source of funds & 5 & 5 & 5 \\
Revenue by services rendered & 5 & 5 & 5 \\
Other incoming revenue & 5 & 5 & 5
\end{tabular}

International Journal of Nusantara Islam, Vol.06 No.01 - 2018; (20-144) DOI: https://dx.doi.org/10.15575/ijni.v6i1.1929 
Total revenue

Expenditure by services

$5 \quad 5$

Expenditure by functions 
Total expenditure

Other recognised gains/losses

Surplus/deficit

Total fund brought forward (bf)

Total fund carried forward (c/f)

TOTAL

$\begin{array}{ccc}5 & 5 & 5 \\ 5 & 5 & 5 \\ 5 & 5 & 5 \\ 5 & 5 & 5 \\ 5 & 5 & 5 \\ 60 & 60 & 60\end{array}$

Next, waqf disclosure - financial statement information (other financial statements) items listed for this study includes: (1) statement of assets and liabilities; (2) statement of cash flows; (3) notes to the accounts; (4) audit certificate; and (5) auditor index rating. From these five financial statement information (other financial statements) indicators, all three selected awqaf institutions are disclosed for all first four financial statement information (other financial statements) items. However, last financial statement information (other financial statements) item which is auditor index rating are only disclosed by both PWS and PWM as rating are being prepared by the National Audit Department of Malaysia and MUIS is excluded from this rating.

Therefore, all three PWS, PWM and MUIS score 100\% (25 items for both PWS and PWM and 20 items for MUIS) for waqf disclosure - financial statement information (other financial statements). This happens as all three selected awqaf institutions are responsible to prepare such financial statement and being go through external audit processes annually. In overall, it can be concluded that waqf disclosure - financial statement information (other financial statements) practices by PWS, PWM and MUIS is in high level. Table 7 shows the result of analysis on waqf disclosure - financial statement information (other financial statements) for all three selected awqaf institutions.

Table

7.

Waqf Disclosure - Financial Statement Information (Other Financial Statements)

\begin{tabular}{lccc}
\hline \multicolumn{1}{c}{ Items } & PWS & PWM & MUIS \\
\hline Statement of assets and liabilities & 5 & 5 & 5 \\
Statement of cash flows & 5 & 5 & 5 \\
Notes to the accounts & 5 & 5 & 5 \\
Audit certificate & 5 & 5 & 5 \\
Auditor index rating & 5 & 5 & $0^{*}$ \\
TOTAL & 25 & 25 & $\mathbf{2 0}$ \\
\hline
\end{tabular}

${ }^{*}$ MUIS is excluded as this item is prepared by National Audit Department of Malaysia

Last but not least, waqf disclosure - non-financial performance information items listed for this study includes: (1) performance target and objectives; (2) input; (3) output; (4) outcome; (5) efficiency; (6) effectiveness; (7) productivity measures; and (8) customer satisfaction measures. From these eight non-financial performance information indicators, all three selected awqaf institutions are disclosed for output item. In addition, both PWM and MUIS disclosed for performance target and objectives, input and outcome items. However, none of selected awqaf institutions are disclosed on efficiency, effectiveness, productivity measures and customer satisfaction measures items.

Based on the result, both PWM and MUIS are leading for waqf disclosure - non-financial performance information when it scores $50 \%$ (20 items). On the other hand, PWS only scores $25 \%$ (5 items). Interestingly, performance and achievement provided by PWM are tallied with its key 
performance index (KPI). In overall, it can be concluded that waqf disclosure - non-financial performance disclosure practices by MUIS and PWM is in moderate level, while PWS waqf 
disclosure - non-financial performance information is still in weak level. Table 8 shows the result of analysis on waqf disclosure - non-financial performance information for all three selected awqaf institutions.

Table

8.

Waqf Disclosure - Non-Financial Performance Information

\begin{tabular}{lccc}
\hline \multicolumn{1}{c}{ Items } & PWS & PWM & MUIS \\
\hline Performance target and obiectives & 0 & 5 & 5 \\
Input & 0 & 5 & 5 \\
Output & 5 & 5 & 5 \\
Outcome & 0 & 5 & 5 \\
Efficiency & 0 & 0 & 0 \\
Effectiveness & 0 & 0 & 0 \\
Productivity measures & 0 & 0 & 0 \\
Customer satisfaction measures & 0 & 0 & 0 \\
TOTAL & $\mathbf{5}$ & $\mathbf{2 0}$ & $\mathbf{2 0}$ \\
\hline
\end{tabular}

The overall analysis of the waqf disclosure practices index (financial and non-financial) is summarized in Figure 1. Figure 1 shows the result of analysis on waqf disclosure index covering both financial and non-financial elements for this study which are corporate information, strategic information, financial performance information, financial statement information and non-financial performance information. The figure shows financial statement information (statement of financial position, statement of comprehensive income and other financial statements) was the highest disclosure practice by selected awqaf institutions when it scores $100 \%$ (385 out of 385 items), followed closely by strategic information $68.9 \%$ (62 out of 90 items), financial performance information $66.7 \%$ (80 out of 120 items), corporate information $61.7 \%$ (74 out of 120 items) and finally by non-financial performance information $37.5 \%$ (45 out of 120 items).

In overall, MUIS is leading in waqf disclosure for both financial and non-financial elements where it scores $87.6 \%$ (241 out of 275 ) disclosure practices. This followed closely by PWM with $85.7 \%$ scores (240 out of 280 items) and finally PWS which scored 58.9\% (165 out of 280 items). Besides, total waqf disclosure practices for these three selected awqaf institutions are $77.4 \%$ (646 out of 835 items), which considered in good practices. However, it still undeniable fact for these three selected awqaf institutions to improve their waqf disclosure practices in the future. This can be further summarized in the Table 9. 


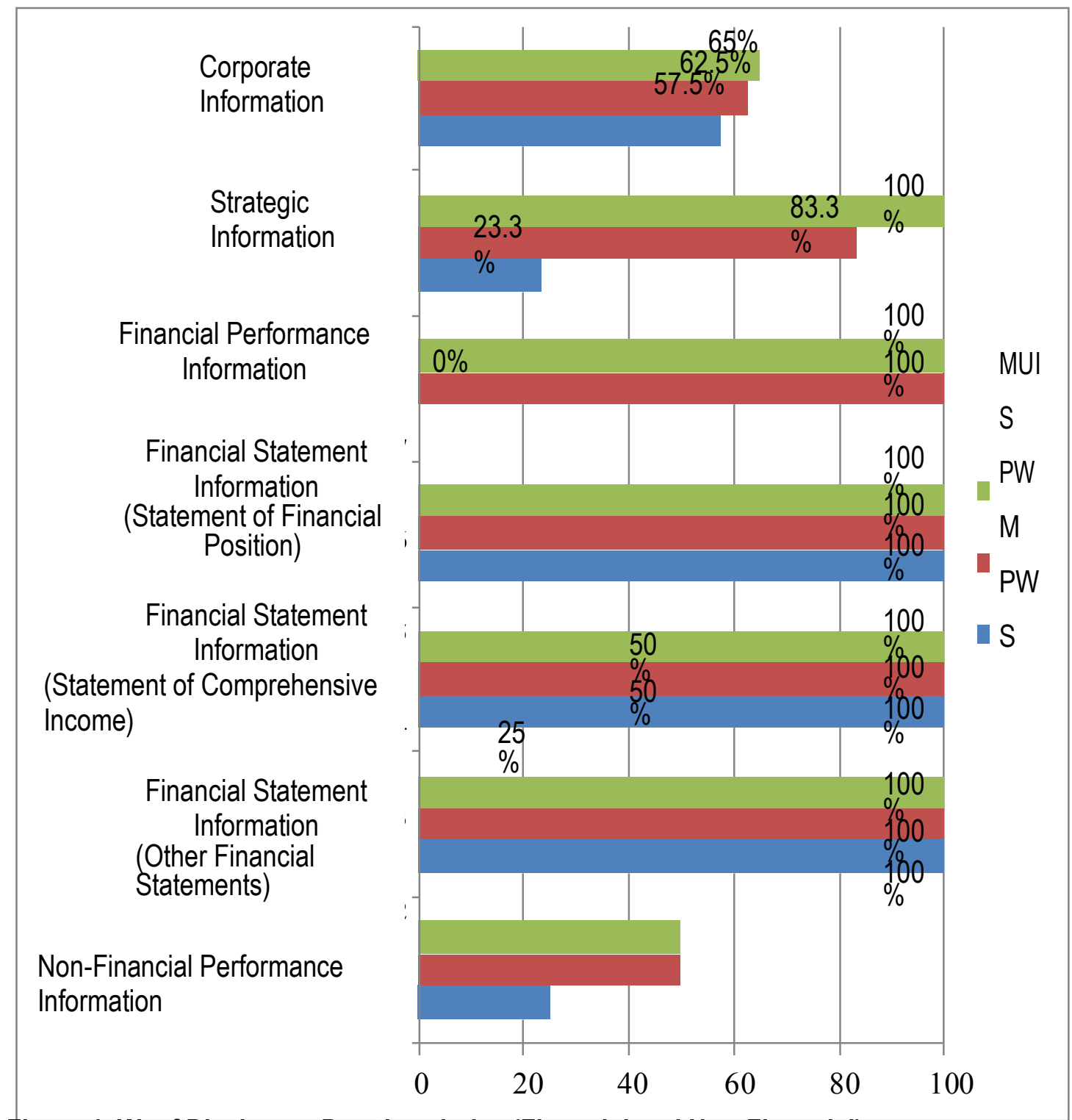

Figure 1. Waqf Disclosure Practices Index (Financial and Non-Financial)

Table

9.

Tabulation of Waqf Disclosure Practices Index (Financial and Non-Financial)

\begin{tabular}{|c|c|c|c|c|c|c|}
\hline \multirow[t]{2}{*}{$\begin{array}{c}\text { Waqf } \\
\text { Disclosure }\end{array}$} & \multicolumn{2}{|c|}{ PW } & \multicolumn{2}{|c|}{ PW } & \multicolumn{2}{|c|}{ MUIS } \\
\hline & $\begin{array}{c}\text { No. } \\
\text { of } \\
\text { Disclose }\end{array}$ & $\begin{array}{c}\text { No. } \\
\text { of } \\
\text { Undisclose }\end{array}$ & $\begin{array}{c}\text { No. } \\
\text { of } \\
\text { Disclose }\end{array}$ & $\begin{array}{c}\text { No. } \\
\text { of } \\
\text { Undisclose }\end{array}$ & $\begin{array}{c}\text { No. } \\
\text { of } \\
\text { Disclose }\end{array}$ & $\begin{array}{c}\text { No. } \\
\text { of } \\
\text { Undisclose }\end{array}$ \\
\hline $\begin{array}{l}\text { Corporate } \\
\text { Strategic } \\
\text { Financial } \\
\text { Performance }\end{array}$ & $\begin{array}{l}23 \\
7 \\
0(0 \%)\end{array}$ & $\begin{array}{l}17(42.5 \%) \\
23(82.7 \%) \\
40(100 \%)\end{array}$ & $\begin{array}{l}25 \\
25 \\
40 \\
(100 \%)\end{array}$ & $\begin{array}{c}15(37.5 \%) \\
5(23.7 \%) \\
0(0 \%)\end{array}$ & $\begin{array}{l}26 \\
30 \\
40 \\
(100 \%)\end{array}$ & $\begin{array}{c}14(35 \%) \\
0(0 \%) \\
0(0 \%)\end{array}$ \\
\hline $\begin{array}{l}\text { Financial } \\
\text { Statement } \\
\text { Information } \\
\text { (Statement of }\end{array}$ & $\begin{array}{l}45 \\
(100 \%)\end{array}$ & $0(0 \%)$ & $\begin{array}{l}45 \\
(100 \%)\end{array}$ & $0(0 \%)$ & $\begin{array}{l}45 \\
(100 \%)\end{array}$ & $0(0 \%)$ \\
\hline
\end{tabular}


Financial and Non-Financial Disclosure Practices in Selected Awqaf Institutions

\begin{tabular}{|c|c|c|c|c|c|c|}
\hline $\begin{array}{l}\text { Financial } \\
\text { Statement } \\
\text { Information } \\
\text { (Statement of } \\
\text { Comprehensi }\end{array}$ & $\begin{array}{l}60 \\
(100 \%)\end{array}$ & $0(0 \%)$ & $\begin{array}{l}60 \\
(100 \%)\end{array}$ & $0(0 \%)$ & $\begin{array}{l}60 \\
(100 \%)\end{array}$ & $0(0 \%)$ \\
\hline $\begin{array}{l}\text { Financial } \\
\text { Statement } \\
\text { Information (Other }\end{array}$ & $\begin{array}{l}25 \\
(100 \%)\end{array}$ & $0(0 \%)$ & $\begin{array}{l}25 \\
(100 \%)\end{array}$ & $0(0 \%)$ & $\begin{array}{l}20 \\
(100 \%)\end{array}$ & $0^{*}(0 \%)$ \\
\hline $\begin{array}{l}\text { Non-Financial } \\
\text { Performance }\end{array}$ & $5(25 \%)$ & $35(75 \%)$ & $\begin{array}{l}20 \\
(50 \%)\end{array}$ & $20(50 \%)$ & $\begin{array}{l}20 \\
(50 \%)\end{array}$ & $20(50 \%)$ \\
\hline $\begin{array}{l}\text { Intormation } \\
\text { TOTAL }\end{array}$ & $\begin{array}{c}165 \\
(58.9 \%\end{array}$ & 115 & $\begin{array}{c}240 \\
(85.7 \%\end{array}$ & 40 (14.3\%) & $\begin{array}{c}241 \\
(87.6 \%\end{array}$ & $34(12.3 \%)$ \\
\hline
\end{tabular}

"MUIS is excluded as this item is prepared by National Audit Department of Malaysia 
Moreover, based on MUIS annual report from 2011 to 2016, several interesting and advanced waqf disclosure practices by MUIS are highlighted. First, for year 2011 to 2015, MUIS financial statements are audited by PricewaterhouseCooper (PwC), while in year 2016, MUIS financial statement is audited by Ernst \& Young (EY). This shows the credibility of MUIS financial statements as it being audited by Big 4 (top four audit firm in the world). Moreover, a change in audit firm among Big 4 also shows possible audit rotation for every 5 years, another best practice implemented by MUIS.

Second, MUIS has a separate set of financial statements reported together in its annual reports, which divided into zakat fitrah, zakat and waqf financial statements. Each set of financial statement contain statement of financial position, statement of comprehensive income, statement of cash flow and statement of changes in equity and notes to the account, which shows proper and comprehensive reporting according to accounting standards by MUIS.

Third, audit process has been conducted for each waqf projects individually and reported individually in the notes to the account. For each waqf project presented in the notes to the account, it contains both income statement (income, expenditure, provision to beneficiaries, gain/loss on fair value of waqf properties/investment and accumulated waqf funds) and balance sheet (capital, fair value, accumulated funds, non-current assets, current assets, current liabilities, non-current liabilities) items. In addition, for those waqf projects, which are not being audited during the financial year, are listed accordingly in the notes.

Fourth, MUIS has published its latest 2016 annual report on the website, supporting accountability paradigm as compared to other waqf institutions in Malaysia which not yet to disclose their latest annual report at the present.

Last but not least, by having a list of waqf beneficiaries such as NGOs, mosques and volunteers, it makes a clear picture on the waqf impact, concerning the beneficiaries. Besides, waqf outcomes and impacts are well disclosed by presenting both summary of fact and figures in details in MUIS annual reports. Summary of the waqf outcomes and impacts disclosed in MUIS annual report is tabled in the following Table 10.

Table 10

Summary of Waqf Outcomes and Impacts Disclosed in MUIS Annual

\begin{tabular}{|c|c|}
\hline Reports / Projects & Measurements / Impacts \\
\hline $\begin{array}{l}\text { Enhancing the Community's Religious } \\
\text { Life - Adult Islamic Learning (ADIL) Program }\end{array}$ & $\begin{array}{l}\text { - No of mosques offering ADIL program } \\
\text { - No of classes offering ADIL program }\end{array}$ \\
\hline Strengthening Madrasah Education & $\begin{array}{l}\text { - Professional development hours provided } \\
\text { - Hours of weekly lesson plan discussions conducted } \\
\text { - No of teachers completed Understanding by Design (UBD) } \\
\text { training } \\
\text { - No of teachers identified to be UBD pioneers }\end{array}$ \\
\hline Supporting Asatizah Development & $\begin{array}{l}\text { - Asatizah registered on Asatizah Recognition Scheme } \\
\text { (ARS) } \\
\text { - Hours of training }\end{array}$ \\
\hline $\begin{array}{l}\text { Strengthening Religious Resilience Via } \\
\text { Quality Islamic Education }\end{array}$ & $\begin{array}{l}\text { - ADIL enrolment - increase in registration percentage } \\
\text { - Percentage of ADIL module satisfaction - enrich and } \\
\text { relevant }\end{array}$ \\
\hline Islamic Education for the Young & - Young involved during the year \\
\hline
\end{tabular}




\begin{tabular}{|l|l|}
\hline Assistance for Low Income Families & - No of families assisted \\
& - Naqf spent for poor and needy families \\
\hline $\begin{array}{l}\text { Social Trust \& Community } \\
\text { Engagement - Harmony Centre }\end{array}$ & - Percentage of non-Muslim visitors during the year \\
\hline $\begin{array}{l}\text { Fostering a Culture of Blessings to All } \\
\text {-F.A.I.T.H Project }\end{array}$ & - No of refugees benefited \\
& - No of relief pack provided to refugees \\
\hline $\begin{array}{l}\text { Service Beyond Our Community - Lets } \\
\text { Share a Meal Program (LSMP) }\end{array}$ & - No of residents received LSMP \\
\hline $\begin{array}{l}\text { Our Mosques - More Prayer Space } \\
\text { Added }\end{array}$ & - No of nolunteers involved with LSMP \\
\hline $\begin{array}{l}\text { Asset Development -Waqf Education } \\
\text { Fund (Waqf Ilmu) }\end{array}$ & - No of prayer space (in capacity) added during the year \\
& - No of fund distributed toward beneficiaries during the year \\
\hline
\end{tabular}

Source: Extracted from MUIS Annual Reports 2011-2016

\section{CONCLUSION}

Having good waqf disclosure practices is important especially for awqaf institutions as it have various stakeholders and faced accountability from both internal parties such as board, staffs, waqif and beneficiaries and also from external stakeholders such as government, media, communities and public at large. This study evaluates the waqf disclosure index covering both financial and nonfinancial elements by three selected awqaf institutions in Malaysia and Singapore, which are Perbadanan Wakaf Selangor (PWS), Pusat Wakaf MAIWP Sdn Bhd (PWM) and Majlis Ugama Islam Singapura (MUIS).

Based on the findings of this study, it can be concluded that the tendency of waqf disclosure for both financial and non-financial elements are generally in good practices. Among all five waqf disclosure elements, financial statement information was the highest disclosed element when it recorded 100\% (385 out of 385 items) disclosed by all three selected awqaf institutions. On the other hand, non-financial performance information was the lowest disclosed when only $37.5 \%$ (45 out of 120 items). This shows more action needed especially by awqaf institutions to disclose on nonfinancial performance elements.

Besides, this study also highlighted and discussed on the good waqf disclosure practices by MUIS that potentially to become as a benchmark by other awqaf institution in preparing their waqf disclosure in the future. Specifically, good initiative by MUIS by providing a clear waqf outcomes and impacts disclosure from waqf activities and projects are crucially needed and become as a good example to other awqaf institutions.

Future research should extend this study by covering more awqaf institutions either in Malaysia as specific and Southeast Asian countries in general. Besides, waqf disclosure practice index used in this study can also being extended by using the index to analyze other Islamic non-profit organizations' in Malaysia and other Islamic countries. In addition, future research could also examine in depth on waqf disclosure on outcomes and impacts based on waqf activities and programs conducted by other awqaf institutions. It would be a very interesting waqf disclosure on outcome and impacts can be analyzed and compared among awqaf institutions. 


\section{References}

Abdul Rahman, A. R. (2003). Accounting Regulatory Issues on Investments in Islamic Bonds, International Journal of Islamic Financial Services, 4(4), 1-11.

Cizakca, M. (2002). Latest Developments in the Western Non-Profit Sector and the Implications for Islamic Awqaf. In Islamic Economic Institutions and the Elimination of Poverty, Leicester: The Islamic Foundation (pp. 63-96).

Gray, R., Owen, D., \& Dams, C. (1996). Accounting and Accountability: Changes and Challenges in Corporate Social and Environmental Reporting. Prenctice Hall Europe, Hemel Hempstead.

Hisham, Y. (2006). Waqf Accounting in Malaysian State Islamic Religious Institutions: The Case of Federal Territory SIRC. (Doctoral Dissertation, International Islamic University of Malaysia).

Ihsan, H. (2007). An Exploratory Study of Waqf Accounting and Management in Indonesian Waqf Institutions: The Cases of Dompet Dhuafa and UII Waqf Foundations. (Doctoral Dissertation, International Islamic University of Malaysia).

Ihsan, H., \& Adnan, M. A. (2009). Waqf Accounting and the Construction of Accountability. In International Conference in Waqf Laws and Management: Reality and Propects. Kuala Lumpur.

Kamaruddin, M. I. H, \& Ramli, N. M. (2015). Enhancing Financial Accountability of Islamic Philanthropic Organizations Through Financial Disclosure. Online Journal Research in Islamic Studies, 2(1), 29-42.

Laughlin, R. C. (1990). A Model of Financial Accountability and the Church of England. Financial

Accountability \& Management, 6(2), 93-114.

MAIWP. (2011). Sejarah Penubuhan. Majlis Agama Islam Wilayah Persekutuan (MAIWP).

Available [Online] at, http://www.maiwp.gov.my/i/index.php/en/mengenaikami/sejarah- penubuhan (Accessed on 18 December 2017).

Masruki, R., Hussainey, K., \& Aly, D. (2016). Expectations of Stakeholders on the Information Disclosure from the Malaysian State Islamic Religious Councils (SIRCs) Reporting. Global Review of Accounting and Finance, 7(2), 112-128.

MUIS. (2017). Wakaf. Majlis Ugama Islam Singapura (MUIS). Available [Online] at, https://www.muis.gov.sg/wakaf/index.html (Accessed on 15 December 2017). 
PWS. (2017). Perbadanan Wakaf Selangor (PWS). Available [Online] at, http://www.wakaf selangor.gov.myl (Accessed on 15 December 2017).

Ramli, N. M., \& Kamaruddin. M. I. H. (2017). Disclosure of Web-Based Accountability: Evidence from Zakat Institutions in Malaysia. $5^{\text {th }}$ South East Asia International Islamic Philanthropy Conference 2017 (SEAIIPC 2017), 14-16 February, Avillion Hotel, Melaka, Malaysia.

Rani, M. A. M., \& Aziz, A. A. (2010). Waqf Management and Administration in Malaysia: Its Implementation from the Perspective of Islamic Law. Malaysian Accounting Review, 9 , 115-121.

Shafii, Z., Yunanda, R. A., \& Rahman, F. K. (2014). Financial and Operational Measures of Waqf Performance: The Case of State Islamic Religion Council of Singapore and Malaysia, In Seminar Waqf Iqlimi 2014, 345-359, 29 April, Negeri Sembilan, Malaysia.

Zain, S. R. M. (2005). Determinants of Financial Reporting Practices on Waqf by Malaysian State Islamic Religious Council in Malaysia. (Unpublished Master Dissertation, International Islamic University of Malaysia).

Zuki, M. S. M. (2012). Waqf and Its Role in Socio-Economic Development. ISRA International Journal of Islamic Finance, 4(2), 173-178. 